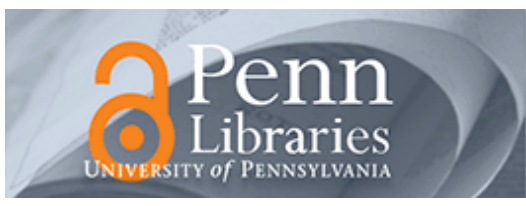

University of Pennsylvania ScholarlyCommons

Departmental Papers (Classical Studies)

Classical Studies at Penn

2012

\title{
The Latinate Tradition as a Point of Reference
}

Joseph Farrell

University of Pennsylvania, jfarrell@sas.upenn.edu

Follow this and additional works at: http://repository.upenn.edu/classics_papers

Part of the Classics Commons

\section{Recommended Citation (OVERRIDE)}

"The Latinate Tradition as a Point of Reference." In Literacy in the Persianate World: Writing and the Social Order, ed. Brian Spooner and William Hannaway. Philadelphia: University of Pennsylvania Press (2012). 360-387.

This paper is posted at ScholarlyCommons. http://repository.upenn.edu/classics_papers/86

For more information, please contact repository@pobox.upenn.edu. 


\title{
The Latinate Tradition as a Point of Reference
}

\begin{abstract}
The history of Persian as an imperial language, as a vehicle of cultural continuities, and as a focus of communal identity, whether of an ethnic, religious, aesthetic, or intellectual nature, is one of the great sagas of civilization. As such, it demands comparison with similar stories if we are to understand the processes at work, both in their general similarities and in their specific differences. In this essay I will consider the cultural empire of Latin in comparison to that of Persian in an effort to determine to what extent these two remarkable traditions are able to illuminate one another and to state as clearly as possible those aspects that resist explanation.
\end{abstract}

\section{Disciplines}

Arts and Humanities | Classics 


\section{The Latinate Tradition as a Point of Reference}

JOSEPH FARRELL

\section{INTRODUCTION}

$\mathrm{T}$

The history of Persian as an imperial language, as a vehicle of cultural continuities, and as a focus of communal identity, whether of an ethnic, religious, aesthetic, or intellectual nature, is one of the great sagas of civilization. As such, it demands comparison with similar stories if we are to understand the processes at work, both in their general similarities and in their specific differences. In this essay I will consider the cultural empire of Latin in comparison to that of Persian in an effort to determine to what extent these two remarkable traditions are able to illuminate one another and to state as clearly as possible those aspects that resist explanation.

\section{GENERAL COMPARISON}

Let me begin by stating the obvious points of similarity and difference between these objects of inquiry. Both the Romans and the Achaemenians of Persia controlled important empires during antiquity. Both of these empires were later "revived" as the Carolingian and Sasanian Empires. The former quickly broke apart through dynastic squabbling; the latter lasted longer, but was then absorbed by the more powerful imperial force of Islam. In both cases, however, even in the absence of a single political center, Latin and Persian continued to exert enormous influence over the cultural life of Europe and the Islamic Caliphate during the late medieval and early 
modern periods. To this extent, the histories of Latin and Persian as imperial languages have been remarkably parallel.

There are, of course, limits to this parallelism as well as some very pointed differences. In particular, the specific trajectories followed by the two languages differ considerably; for, if we divide the histories of Latin and Persian each into two broadly-defined periods, "antiquity" and "afterwards," we find that these histories move almost in opposite directions.

\section{History of Latinity}

Early Period (Antiquity), ca. 750 BC-AD 426

Throughout antiquity, Latin is the language of a very powerful and longlived political empire. The Roman state experienced an extended and virtually uninterrupted period of expansion and consolidation of power that began perhaps with the foundation of the city in the mid-8th century BC, or at any rate with the foundation of the Roman Republic in about 500 BC. By the late 3rd or certainly the mid-2nd century BC, this republic had developed into a de facto empire, although official reorganization of the state on the basis of this reality did not occur until more than another century had passed. The territory encompassed by this empire remained relatively stable until the end of the Severan dynasty in AD 235. Its fortunes waxed and mainly waned for another couple of centuries until the last Western emperor, Romulus Augustulus, was executed in 476, after which time the Western empire ceased to exist. The eastern empire of course survived as the Byzantine state, but for many reasons it makes sense to consider this a distinct entity.

Latin was the native language of the Romans, and it became the administrative language of the Roman Empire. In the course of Rome's expansion to imperial proportions, the language, too, took on an imperial character. That is to say, it came to be more widely used not only in administration but for many purposes, from the most humble, quotidian exchanges to the most elevated forms of literary expression. In Italy and in most of the western provinces as well as in Dacia (Romania) in the east, it permanently replaced all the indigenous languages. It did not take hold to the same extent in Britain or in some areas of north-central Europe, but it did so in north Africa, where it held sway until the Arab conquest. Only in the eastern provinces did Greek and other languages, such as Aramaic, continue to be used 
for non-administrative purposes. ${ }^{1}$ At its height, the Roman Empire covered an area of almost two million square miles and claimed, on a conservative estimate, about fifty-six million subjects. ${ }^{2}$ The east, however, was more populous than the west, so Latin was probably the primary language of no more than twenty-two million. ${ }^{3}$

\section{Later Period (Medieval and Modern), AD 426-present}

By the end of antiquity, Rome's empire had given way to incursions by alien forces that held localized political power in different regions across a disunified Europe-a situation that persists (the European Union notwithstanding) down to the present day. But throughout the former Western empire, Latin for centuries continued to hold sway as the language of the people and even to be adopted as the court language of some successor states.

Throughout late antiquity and even during the middle ages, the Latin of the elite remained remarkably stable, even as Latin underwent a series of significant changes that ultimately brought about the rise of the various Romance languages. At the same time, though, the institutional support of the Catholic Church and the reform efforts of educators like the Carolingian courtier Alcuin ensured that the ancient language maintained much of its integrity and remained in use as a language of learning, administration, and diplomacy. ${ }^{4}$ s a result, it is probably safe to say that most of the Latin that has ever been written should have been quite intelligible to anyone who had received a grammatical education in any period from the 3 rd century BC to the present day.

\section{History of Persian}

Early Period (Antiquity), ca. 750 BC-AD 637

Politically, we must speak (as was suggested above) not of one Persian Empire, but at least two-the Achaemenian (550-330 BC) and Sasanian (226-651) empires - as well as periods of domination by foreign powers, primarilyAlexander the Great and his Hellenistic successors (330-250 BC) and the Parthians (250 BC-AD 226). As political power changed hands, use of the Persian language ebbed and flowed, and the language itself underwent significant changes. Under the Achaemenians, for instance, an archaic form of the language known to linguists as Old Persian came to be written for the first time. How long this language had been spoken, and whether 
it was in fact still used outside of the inscriptions that begin to appear only in about $650 \mathrm{BC}$, we do not know. ${ }^{5}$ We do know that already by the end of the Achaemenian period a simpler form of the language, Middle Persian, was coming into use; we also know that for administrative purposes the Achaemenians adopted the language and bureaucratic structures of the Elamites, their predecessors in the region. So, it is in fact somewhat misleading to say that Old Persian was the language of the Achaemenian Empire. Under Alexander, his successors, and the Parthians, Middle Persian continued to be used for various purposes, along with other Iranian languages; but it did not gain the status of an imperial language until the Sasanians came to power, claiming to revive the ancient Persian Empire of the Achaemenians and promoting the Persian language along with other cultural institutions.

The achievements of the Sasanians themselves were undeniably important; but, for our purposes, their greatest contribution was to create the conditions under which Persian would achieve its most notable success, after the Sasanian empire came under Arab rule. Nevertheless, even if the greatest glories of Persian were still in the future, througout the history of ancient Iran a succession of languages-Elamite, Greek, Aramaic, and others-came and went, each serving for a time as the dominant lingua franca or koine, while Persian, in one form or other, endured. ${ }^{6}$

\section{Later Period (Medieval and Modern), AD 637-present}

It was with Arab contact that Persian underwent its most decisive change and, as New Persian, became an imperial language under Islam. To an equal or greater extent than Latin in the West, Persian became a language not only of administration, but of literature, of the other arts and sciences, of business, and of everyday exchange. This was true not only within the traditional borders of ancient Iran. Persian was the language of literacy and administration par excellence throughout the early Ottoman Empire and extended its reach eastwards to western China and south into peninsular India. Most remarkably, as Morgan and Aslam explain in this volume, it was used as a lingua franca among traders in Mongol China and it enjoyed official status as the administrative language of at least one important state, the Mughal Empire (1526-1857), that was situated largely outside the territory of any previous Persian empire and entirely outside the Iranian plateau.

Like all living languages, New Persian has continued to develop over its fourteen centuries of existence; but it continues to be the mother tongue of 
some sixty million modern Iranians, and at least ten million Afghans, Tajiks, and Uzbeks, who would recognize the New Persian of the 9th century AD (but not Middle or, still less, Old Persian) as a form of their own language, much as a modern English speaker would recognize Shakespeare's language (but not the language of Beowulf) as an early form of his own.

\section{Comparison}

Through this comparison, it is clear that the history of Latin is inverted with respect to that of Persian. Latin derives its power mainly from developments in antiquity, above all from the fact that it was the administrative language of the Roman Empire. Its significance steadily lessened througout the medieval and modern periods, so that its current position is largely vestigial; it has no native speakers and so is widely regarded as a "dead language." This is perhaps the expected trajectory for a language that achieved imperial status over two thousand years ago: a robust, creative early period followed by centuries of living largely on prestige accumulated in the distant past.

Viewed against this paradigm, the experience of Persian is all the more remarkable. Beginning in antiquity as the language of a polyglot empire controlled by one in a series of dynastic groups that governed ancient Iran, centuries later it experienced a resurgence under rulers who drew upon the prestige of Achaemenian achievements to establish and exploit the idea of a connection with ancient Persia. Only with the conquest of the Sasanians by the Arabs, however, were the conditions created that allowed Persian to become a truly imperial language, not only in Iran but in other parts of the Islamic world. Of course, the imperial status of Persian largely evaporated with the colonization of the Islamic world by Western powers; but New Persian continues to be widely spoken, and the political importance of modern Iran is hardly negligible. In a way that is simply not true of Latin, the imperial history of Persian remains an open book.

\section{IMPACT OF OTHER IMPERIAL LANGUAGES (GREEK AND ARABIC)}

The respective histories of Latin and Persian are thus rather different from one another. But these histories do share at least one other remarkable feature. The most significant periods in the development of Latin and Persian as imperial languages were inaugurated and in large measure caused by contact 
with other imperial languages. In the case of Latin that language was Greek, and in that of Persian, it was Arabic. About this aspect of Persian I will say little beyond referring to the excellent account of Perry in this volume. I will try to bring out some of the parallel aspects concerning Latin and Greek.

Greek influence on the Romans goes back a long way, but it seems clear that during the $3 \mathrm{rd}$ and $2 \mathrm{nd}$ centuries BC, the quantity and especially the quality of this influence i ncreased s ignificantly. The Ro mans th emselves saw things this way: to quote the poet Horace, after the Roman conquest of Greece in the 2nd century BC, "conquered Greece made her uncouth conqueror her captive." 7 Greek influence at this time takes a number of forms. One of the most notable is the energy with which the Romans set about acquiring a national literature specifically fashioned along Greek lines, involving the translation and creative adaptation of canonical texts, chiefly dramatic extending to epic and other genres as well. This is such a familiar story that it is important to understand how strange it is. One student of the phenomenon has recently proposed the following, hypothetical analogy: An English schoolmaster is shipwrecked on the West African coast. Carried inland by slave traders, he makes himself useful to the most powerful chief of Ife. There his old skills as scholar and teacher come to the fore, and, almost by accident, he launches one of the world's great literatures when he translates Paradise Lost into Yoruba and adapts the plays of Dryden for a local festival. ${ }^{8}$

This sounds, and is, comically far-fetched, but it was in just such terms that the Romans imagined the founding of Latin literature by Livius Andronicus, a prisoner of war who allegedly launched Latin literature by translating the Odyssey from Greek into Latin and by adapting Greek New Comedy for the Roman stage. The truth of course has to be more complex; but our near total lack of literary material antedating Livius makes it very difficult to say more than that; and the ubiquitous presence of specific Greek models behind almost every work of Latin literature over the next several centuries makes the importance of Greek impossible to deny.

What set Greek apart from other foreign languages, however, was its immense cultural prestige. Even those rough-and-ready Roman generals of the 3 rd century BC, who (we are told) took no interest whatsoever in art, literature, or anything except war and politics, had to acknowledge that Greek was the language not only of international culture but also of international relations. Over time, the Roman elite became familiar with Greek both from this point of view and from the study of Greek literature, philosophy, and 
the other arts. The process of "hellenization" was occasionally controversial at Rome, and some strain of resistance to this process must have been crucial to the long-term development of Latin culture. In fact, it remains an unanswered question why the Romans - uniquely, so far as we know, in the Hellenistic world-decided to create a national literature in Latin on the Greek model, rather than simply adopting Greek literary culture entirely, language and all. In fact, this almost happened. When members of the Roman elite in the 3rd century BC began to write, they adopted not only the conventions of established Greek genres, such as history; they even wrote in Greek. ${ }^{9}$ But within a generation of two, a new and more lasting trend began. From the late 3rd century onwards, Latin literature took the form of translations and adaptations of Greek models, gradually gaining more independence but never quite losing a specifically Greek point of reference. In all periods, Roman intellectuals are explicit about this fact and endorse the necessity for serious writers to look to Greek models of excellence. ${ }^{10}$

This is just one of the ways in which Greek had a decisive influence on Latin (and we shall consider some others as well), and one of the reasons that we can say that Greek had as important an impact on Latin as Arabic did upon Persian. If we press this comparison a bit harder, though, we quickly find that it, too, has limits. If one were to ask, Is Latin to Greek as Persian is to Arabic?, then the answer from several points of view would be, No; rather, Arabic, the language of the conqueror, is the proper correlative of Latin in this analogy, as Greek is that of Persian. Consider: the Romans' decisive encounter with Greek was at the time when their own imperial expansion put them in conflict with the remnants of Alexander's empire, a Greek-speaking super-state that had broken up into a number of smaller kingdoms of still significant size that were still Hellenistic in their cultural and linguistic character. These states, while in certain ways culturally more advanced than Rome, became politically subservient, while Rome adopted many Greek ways and made Greek culture more familiar than it had been in the western Mediterranean. It would be going too far to say that "the same thing happened" in the Islamic conquest of the Sasanian Empire; but similarities do exist. The Arab caliphate took political power over the former Sasanian state, but Arabic language and culture also absorbed a great deal from Persian (as it did from Greek, Aramaic, and the other traditions with which it came into contact) and exported much of what it absorbed throughout the Islamic world. Thus Persian became the second language 
of the Islamic world. This situation has something in common with the one that obtained in the Roman provinces of northern Africa in the 2nd or 3rd century $\mathrm{AD}$, when an educated person's proudest boast was to be utriusque linguae peritus, "thoroughly educated in both languages," where "both languages" means Latin and Greek-regardless of the individual's native language (which might be Punic, Berber, or anything else). Indeed, under the Roman empire we witness such phenomena as the rhetor Favorinus (ca. AD 80-150), who was born in Arlate (Arles), the first Roman town built in Gaul after Julius Caesar's victory over Gnaeus Pompeius in the civil war, and who under the Emperor Hadrian became one of the world's greatest experts not in Latin but in Greek rhetoric.

\section{CLASSICAL AND VULGAR DIALECTS}

John Perry raises the question of homoglossia as a factor in the stability and longevity of Persian, holding that the literary language evolved along with the everyday idiom in such a way as to insure that they remained in close contact. The history of the relationship between literary and spoken Latin may be instructive here.

Literary Latin, as I have noted, is a relatively stable medium of expression. Some of the earliest prose that survives from about the 3rd century $\mathrm{BC}$ differs in style, but hardly at all in grammar and syntax, from much of what was written in the $2 \mathrm{nd}, 3 \mathrm{rd}$, 4 th, or 5 th centuries AD. Many medieval writers cultivated a Latin style that differed little from that of the ancient authors, and most Renaissance and Neolatin authors were stricter still in their observance of classical norms. It is easy to get the impression from written sources that the language was inherently quite uniform and resistant to change. But this is only part of the story.

Alongside the classical dialect was another, which is known to scholars as "Vulgar Latin." The name is not primarily pejorative: it denotes the language spoken by "the crowd" (vulgus) as opposed to the one best represented by authors who had attained a "high tax-bracket" (classici). ${ }^{11}$ Of course, our knowledge of this dialect in antiquity stems almost exclusively from traces of it in written sources, so that we cannot confront it in a form uncontaminated, as it were, by the elite dialect. But this very fact shows that the elite and the vulgar dialects existed alongside one another for centuries, not just during the middle ages but in antiquity as well. Further proof of this is the 
pattern in which "vulgarisms" occur in ancient texts. Such things are relatively common in early authors, such as the comic poet Plautus $(3 \mathrm{~d}-2 \mathrm{~d}$ c. $\mathrm{BC}$ ), who is concerned to reproduce everyday speech or, at least, to suggest it as much as the metrical conventions of his genre will allow. After Plautus these features then disappear from our texts for generations, never or hardly ever to be found in authors like Cicero, Sallust, Livy, or Tacitus, only to reappear in an inscription or even in the vocabulary or sentence-structure of the Romance languages.

The example of Plautus (and one could cite other authors, like Petronius, who imitate vulgar speech in a literary context) and all other available evidence shows that the two dialects were recognizably distinct. But how far did these differences go? A useful comparison that I have cited before concerns the classical and vulgar Latin equivalents of the English sentence, "I bought a horse."12 If we work backwards from the Romance languages, where we find the sentences "Io ho comprato un cavallo" (Italian) and "Yo he comprado uno caballo" (Spanish), we would conclude that the Latin equivalent would be "Ego habeo comparatum unum caballum." And so it would be-in the vulgar dialect. But the classical Latin equivalent would be "Equum emi." The syntax of the two sentences is identical, as are some elements of the grammar. ${ }^{13}$ Practically everything else, however, differs, from lexicon to word order to aspects of usage and style. ${ }^{14}$ The example is thus useful for illustrating how distant the two Latin dialects could be. We should not therefore assume that they were mutually incomprehensible, however; most of our specimens of vulgar Latin are perfectly intelligible, although uneducated speakers of this dialect might well have been challenged to follow the orotundities of a Ciceronian period from one end to the other. The real point is, first, that they were distinct dialects and, second, that the classical dialect was sufficiently regular to ensure that it would be relatively resistant to change; while the vulgar dialect was much less strict and so relatively open to influences of all sorts.

It may be, then, that the situation in Roman antiquity was similar to that in medieval Persia in that the elite and the everyday forms of the language were at all times reasonably close. What is not clear is why they remained close in these periods, when in the case of later Latin and, apparently, earlier Persian as well, the written and spoken dialects were farther apart. ${ }^{15}$ We will return to this question below in considering the later history of Latin and the development of Romance. 


\section{FACTORS AFFECTING THE DEVELOPMENT OF LATIN AS AN IMPERIAL LANGUAGE IN ANTIQUITY}

In this section I will consider some of the institutions that affected the development of Latin as an imperial language in antiquity, some of which help to explain the stability at least of the elite dialect over such a long period of time. Most but not all of these institutions are in some way products of the extensive Hellenization that took place in Rome beginning in the 3rd century BC. In this section I will not try to give detailed accounts of the parallel Persian instituitions, if any, but instead will refer to discussions of these institutions by experts elsewhere in this volume.

\section{Schools}

The development of Latin grammar is probably the most significant and efficacious factor in creating a form of the language that could and did remain stable and intelligible to people of different circumstances living far apart in space and in time. The fact that grammar became the basis of elementary education throughout the Roman world made its influence, for all practical purposes, universal, in spite of the fact that advanced literacy probably remained rare, by modern standards, throughout antiquity. ${ }^{16}$ All of this was a direct result of Rome's adoption of a Hellenistic literary culture.

During the Hellenistic period, the Greeks developed what they called the techne grammatike. Within it, rules were developed to determine what was correct or incorrect in the form of a word, in the structure of a sentence, and so forth. In this system, that which was correct was simply hellenismos, or "Greekness." What was not correct was barbarismos, i.e., "not Greek." When the Romans began to take a serious interest in understanding and acquiring Greek culture, efforts were made to provide Latin with a grammar on the Greek model, and in this system as well an error was labeled barbarimus, while correctness became latinitas. The effort to adapt Greek grammar to Latin was greatly facilitated by the fact that both languages are highly inflected and in fact quite similar in structure. In vocabulary they are less similar, but there are enough obvious cognates, such as patêr/pater and mêtêr/mater, along with loan words like Latin poeta (< Greek poietes), to convince some in antiquity that Latin was not a separate language at all, but rather a dialect of Greek. ${ }^{17}$ But quite apart from this theory, it is a fact that ancient students of the Latin language - that is, of classical Latin - mod- 
eled their understanding of Latin grammar and syntax as closely as possible on Greek models.

In addition to descriptive elements, the ars grammatica was highly prescriptive in matters of correct morphology and syntax, but also of usage and style. It balanced conservatism with a capacity to evolve by basing proper latinity on five elements, which I list here in order of ascending importance: ratio, which consisted of analogia and etymologia; vetustas; auctoritas; and consuetudo, otherwise known as natura. The first elements assume the existence of an idealized past when language was a rational system that developed analogically and admitted no anomalies. In this ideal past, words possessed their "true meaning" (i.e., their etymology) as well. Of course, the idea that there was such a time suggests the existence of a later period during which anomalies did creep into the system and words started to change their meaning. For this reason, "systems" (i.e., "analogy" and "etymology") are theoretically standards of correctness, but they are relatively weak ones, and in practice grammarians invoke them to explain ancient puzzles more often than to establish meaning in the present, which has drifted away from these archaic standards. Auctoritas, "authority," is a more serious matter. In the ancient grammarian's schoolroom, pupils committed to memory choice passages of approved authors, a canon that was fashioned on the model of Hellenistic scholarship. ${ }^{18}$ One might for instance approve a particular usage because it was found in Vergil. But it was more likely that a schoolmaster of, say, the 4th century might justify an unfamiliar usage in Vergil on the basis of vetustas, "antiquity," noting that a word had changed its meaning since Vergil's time. For this reason, he would advise his students not to imitate Vergil's authority, but to write in accordance with contemporary usage. This is what is meant by consuetudo, "custom," which was also known, remarkably, as natura, "nature." It is this factor, "nature," that is the most effective determinant of proper usage in the present. And what is this nature? In the end, nothing more or less than the grammarian's opinion about the best or most correct way to say any given thing!

In a system like this, in which so much depends on the grammarian's judgment, one might have expected latinitas to become fragmented and multiform. But in fact, the conservative elements in the system, and particularly the memorization of canonical authors as stylistic models, seem to have informed consuetudo or natura to a considerable extent. The result is that the language of the literate, educated classes remained quite stable over 
long stretches of both time and space, and also that the writings of the great grammarians, such as Donatus, exercised a stabilizing effect on post-antique latinity as well, making possible the periodic revivals of classical latinity that took place during the middle ages and especially in the Renaissance.

\section{Cultural Institutions}

In addition to grammar and schooling, the Romans borrowed and adapted from the several Hellenistic kingdoms a number of institutions designed to support their cultural ambitions. These had the direct or indirect effect of fostering the growth of Latin as an imperial language, as they had done with Greek beforehand.

It was the Hellenistic successor-states to Alexander's empire that created these institutions. In the classical period, Greek culture was supported primarily by the institutions of the city state, which tended by their nature to be somewhat limited in size and oriented towards the interests of communities that balanced local and tribal interests against panhellenic ideals. It was a highly philhellenic king of Macedon, Philip II-a man whom traditionalists like Demosthenes could represent as a foreign power and even as a barbarian - who first successfully effected a universal hegemony over Greek political affairs, and then bequeathed to his son Alexander the Great the means for extending this hegemony throughout much of the east. Alexander's empire of course did not outlive him, but it left in its wake a number of powerful superstates that commanded wealth on a scale that no individual polis could match, and that outdid the traditional poleis in willfully asserting their "Greek"—or, as we would say, following Winckelmann, their Hellenistic - cultural identity. It was an overwhelming "will to Greekness" on the part of rulers like the Macedonian general Ptolemy, usurper of the throne of the Pharaohs, that led to the foundation of such institutions as the famous Museum of Alexandria and its library, where the classic works of Greek literature in all fields were collected and where linguistic and philological research on these texts was carried out at a high level.

This process was an important forerunner of and indeed a model for the Romans. In time, Roman leaders mimicked both the ancient centers of culture, such as Athens, and the great Hellenistic rulers in providing institutional support for literary culture. The early period (late 3 rd and 2 nd centuries $\mathrm{BC}$ ) is characterized by the institution of state-sponsored dramatic 
festivals in Rome, at which masterpieces of 5th- and 4th-century Athenian tragedies and comedies were translated and adapted for Roman audiences. Rome of course was not the first state to do something of this sort. Even in the heyday of the Athenian stage, poets such as Aeschylus and Euripides were in demand at the courts of parvenu rulers who wished to enhance their cultural prestige. Later, roving troupes of actors enjoyed something like diplomatic status as they moved about the Hellenistic world, performing classic plays for local audiences. ${ }^{19}$ What is unusual about the Romans' experience is that this sort of participation in Greek literary culture was not sufficient to their purposes. They are the only people known to have created a literature in their own language on this Greek model. In this sense, the Romans' adoption of this institution and their adaptation of it into something of their own, seems to have been decisive.

Libraries were another institution imported to Rome from the Hellenistic world. The first of these were imported literally as the spoils of war. These include the library of King Perseus of Macedon, which was brought to Rome by L. Aemilius Paullus in 168, and that of Aristotle, which L. Cornelius Sulla brought from Athens in 82 . More peaceful and more spectacular was the library of Pergamum, second only to that of Alexandria in the Hellenistic world, which Attalus III bequeathed to the Romans, along with the rest of his kingdom, upon his death in $133 .{ }^{20}$ All of these libraries of course contained books in Greek. The same could be said of some, perhaps most private libraries in the Roman world until the 1st century BC. ${ }^{21}$ But even before that time, Latin scholars had applied themselves not only to providing the language itself with a sound grammatical foundation, but also to establishing the authenticity of their most important literary texts, and so to developing a literary canon. The research of earlier scholars informed the definitive work of M. Terentius Varro, a senator who in his leisure found the time to write some three hundred books, including a major treatise De lingua latina (25 books) and another establishing the authenticity of the twenty-one plays of Plautus that now form that author's literary corpus. ${ }^{22}$ In this activity, Varro was following in the footsteps of Hellenistic scholars in the Alexandrian library. Fittingly, then, Julius Caesar chose Varro to be the head of one of his most symbolic cultural projects, the first public library planned as a new foundation on a grand scale. After Caesar's death the project was completed by one of his associates, C. Asinius Pollio; and soon afterwards Caesar's heir, Augustus, continued Caesar's legacy by 
founding a number of libraries, setting a pattern followed by many subsequent emperors.

Once again, it is worth mentioning an important linguistic feature of Roman libraries. Greek libraries, to the best of our knowledge, contained only Greek books. At least, we know of no special provisions made for books in other languages. But all Roman libraries that we know of were composed of two main reading and storage areas, one devoted to books in Latin, the other to Greek. This feature is to be seen as a correlative to the Romans' adaptation of Greek into Latin drama. The Greek model or models of a typical Roman play would be known to the audience; indeed, they are not infrequently announced and even discussed in the prologue to a comedy. The bicameral plan of a Roman library instantiates the mimetic relationship between these two literatures in architectural form, and invites comparison between original and copy in the belief that the process of imitation and adaptation has been successful..$^{23}$

At length, imperial patronage extended to something like state-funded professorships. Having begun with Greek slaves and freedmen who tutored their Roman masters in Hellenistic culture, scholarship had become by Caesar and Varro's time to a large extent the province of the aristocracy. But in the early Empire the situation changed, and such pursuits became at once less socially distinguished and more professionalized. ${ }^{24}$ It was the Emperor Vespasian (AD 69-79) who began the practice of paying a regular salary of a hundred thousand sesterces to Latin and Greek teachers of rhetoric. ${ }^{25}$ According to Jerome's Chronicle the first person to occupy one of these positions was Quintilian, the great rhetorician and educational theorist. It is to him that we owe our most complete account of the canon of Greek and Latin authors, genre by genre, which forms book 10 of his Institutio oratoria, which begins by advising the parents of future Latin orators to begin educating their children in Greek first, since a knowledge of Greek will be so important to him and Latin will come more naturally, anyway.

\section{Administration}

As I have mentioned in passing, all of these cultural institutions had to be run by someone, and together they formed only a small part of the imperial bureaucracy. The role of administration itself in promoting the use of Latin and in maintaining a high standard of correctness is a topic that has not received much attention from classicists, nor has any possible in- 
teraction between the bureaucratic and the creative spheres been properly investigated. This is so probably because the grammar schools themselves seem to have been the primary vehicle for spreading and maintaining a high standard of literacy. It is possible, however, that we could learn something about the latinate tradition by looking for connections between the activities of poets and clerks, such as William Hanaway finds in the world of the Persian munshi.

One obstacle to such an effort is the comparatively low status that men of letters held in the Roman world. This is one area in which the Romans did not follow the lead of the Greeks. In the classical Greek polis, a gentleman was expected to have considerable knowledge and appreciation of poetry and some ability as well. Really successful poets were held in high esteem, and a few of the most important actually received hero-cult status after their death. This was never true at Rome. Some have posited that in archaic times the Roman aristocracy practiced a musical culture not unlike that of the Greeks; but there is no direct evidence for this, and both the scanty ancient Roman comments about the very distant past and the efforts of some scholars to reconstruct that past are heavily influenced by what we do know about Greece. At any rate, after the point when Latin literature begins to develop in earnest, we find, as w as noted a bove, that virtually all of the important poets are foreigners who lack citizen rights and are in some cases not even free. The situation improves over time, but the position of the poet never becomes in Roman society what it had been in Greece.

One has to admit, then, that the social position of the literatus in Rome was normally less exalted than in medieval Persia. But if the question is, were there Roman writers who made names for themselves in the field of belles-lettres while taking an active role in the imperial bureaucracy, then the answer is yes. To take a famous example, the poet Horace, after fighting on the wrong side of the war between the future Augustus and those who had murdered Augustus' adoptive father, Julius Caesar, somehow obtained a pardon, returned to Rome, and scraped together enough money to purchase a civil service post as scriba quaestorius. This amounted to a franchise that gave Horace control over the reproduction of certain official documents and thus provided him with an income that placed him in the equestrian order, the second-highest wealth bracket in Roman society. With the income derived from this monopoly, Horace was able to devote himself mainly to the poetry that eventually won him a close relationship with Augustus himself. 
From this relationship came a commission to compose a hymn that was sung during the most important religious celebration held during Augustus' principate, the Secular Games, and an invitation - which Horace declinedto become the Emperor's a secretis, his personal secretary.

Horace's example is not unique. Decades later under the Emperor Hadrian, Suetonius, who is known today principally as author of The Lives of the Twelve Caesars, held the same post that Augustus had offered Horace, thus combining the literary career of a scholar rather than a poet with the bureaucratic career of an imperial secretary. At a less exalted level, the freedmen Gaius Verrius Flaccus and Gaius Julius Hyginus both composed important scholarly works on various topics while supporting themselves as, respectively, the head of a school located in Augustus' own house, and as the director of the Palatine Library, directly adjacent to Augustus' house. These individual examples, at least, seem to be rather good parallels to Persian practice.

So, careers like those of several munshis can be found at Rome. But did these careers have any influence in the realm of language? According to Hanaway, "the formal, written, court language of the Persian courts...was created and developed as result of the dynamic interaction of the work of the munshis and the poets." Can the same thing be said of Rome? Horace's work as scriba quaestorius verges very closely on that of the munshi. But if we compare Horace's poetry with the formulaic language of the documents from which he derived his living, it is difficult to see what they might have in common. ${ }^{26}$ Still, it may be possible to find among less famous individuals or groups a more convincing parallel than Horace to the case of the munshi.

We do know, for instance, that from the late 3rd or early 2nd century BC there existed at Rome a collegium scribarum et poetarum, an organization of scribes and poets. ${ }^{27}$ What its nature may have been is very unclear. The word collegium can denote anything from a club to what we might call a political action committee, a guild or union hall, a mutual assistance organization, and so on. Such organizations enjoyed no special status; in fact, they were occasionally suppressed on account of suspected subversive activity. For that matter, exactly what is meant by "scribe" or "poet" is not clear, either. How did one get to be acknowledged as a member of either profession? We simply do not know. And yet the existence of such an organization suggests that the two professions of "poet" and "scribe" were viewed as broadly comparable-and, for that matter, that they were viewed as profes- 
sions, rather than utilitarian chores to be performed by members of the household staff or, conversely, as the appropriate occupations of civilized leisure. They were these things as well, of course; but the existence of the collegium suggests that they were also acknowledged as professions.

What role did poets and scribes have in creating classical latinity? The poet's expertise is clearly visible to us, of course, in distinction to the efforts of gentlemen amateurs; over time, the Romans came to recognize a canon of authors in each of the major genres, and these authors themselves eventually played an important role in defining latinity. We know less about the scribes, but we can catch a glimpse of their influence as well in some of the few documents that survive from the Republic. Chief among these is a senatus consultum, a senatorial decree in response to official consultation by the consuls in $186 \mathrm{BC}$, concerning the spread of Bacchus worship among cities allied with Rome. The document is in two parts, one formally summarizing the senate's decree and written by professional scribes (who evidently were citizens, since they are named in a fashion that normally denotes such status), and another in which the consuls in their own words address the affected parties. At the point where the change occurs, the most recent commentator on this document makes the following interesting observation:

So far all has been reasonably plain sailing, but confusion of thought and expression now sets in...Until now the consuls have been quoting from the senatorial decree framed by professional draughtsmen; now they are telling the local officials what they have to do and, being more used to the sword than the pen, do so in an incoherent way. ${ }^{28}$

In his notes on this passage, Edward Courtney shows that the consuls depart in all sorts of ways from the style employed by the scribes, a style that is entirely consonant with the norms of classical Latin as it was to develop during the time of Cicero and into the Empire. To put it simply, the consuls write much more poorly than do the scribes, according to the standards of classical latinity, of which the consul Cicero several generations later was to become the chief exemplar. This is an impressive example of the influence of professional expertise in forming the language of the Roman elite. For that matter, we know that one particular example of official language was part of the educational system. Cicero tells us that even in his 
day young students were made to memorize the archaic legal code known as the Laws of the Twelve Tables. ${ }^{29}$ Further, it would be easy to demonstrate the stylistic influence of documents such as the a nnales maximi, annual records kept by the state college of pontifices, on such works as Ennius' poetry and Livy's history. ${ }^{30}$ Indeed, from this and other evidence one could probably stitch together a plausible, fairly comprehensive picture of the various ways in which bureaucratic and belletristic pursuits came together, sometimes in the same individual, to define a stable elite dialect. The younger Pliny offers a notable opportunity. Nine books of his letters to friends read very much as epideictic exercises in correct Latin style and literary self-fashioning. The tenth book shares in these qualities, but it is unified as the preceding books are not by the fact that it records Pliny's correspondence with the Emperor Trajan during the period when Pliny was governor of Bithynia. Pliny's style remains recognizable as his own, although it veers in the direction of officialese, especially in phrases that refer to standard policy. Trajan's style is more the uniform production of the imperial chancery, although it, too, is not without touches that suggest the Emperor's personal attention. Here one must bear in mind that Pliny, as governor of an important province, was a significant member of the imperial government: he did not bother the Emperor needlessly, and he had reason to expect that his inquiries would be singled out by Trajan's secretaries for the Emperor's personal attention. If we can extrapolate from what we know about the habits of Trajan's predecessors, we even have some idea of how this process worked at the practical level. ${ }^{31}$ But Trajan's replies to Pliny form only a small part of an enormous volume of correspondence collectively known as imperial "rescripts," responses to inquiries of all sorts that came to the emperor from virtually anyone in the Empire. It was the business of the imperial chancery to handle this correspondence, and of the Emperor to involve himself in particular issues at his discretion. As I have already suggested, Pliny's letters to his friends, to say nothing of the poetry that we know he wrote for his own and his friends' amusement, had little in common with the chancery style of the rescripts. Nevertheless, Pliny's literary style and the chancery style were both subsets of the classical dialect cultivated by the Roman elite, and as such were distinct from the more malleable vulgate that was spoken by the great majority of imperial subjects - if indeed they spoke Latin at all. So in ways such as this, we can glimpse the broad outlines of a collaborative relationship between creative 
writers and bureaucrats and a common purpose in maintaining a uniform, imperial Latin style. If we compare the situation to what we know from the Persian sphere, the main differences are perhaps that the Roman scribe is a less distinct figure than the Persian munshi, that the connections between the world of the scribes and the world of belles lettres are, with a few outstanding (and perhaps misleading) exceptions, less direct, and above all, that literary pursuits as a career conferred less status per se in Rome than they seem to have done in Persia. But the possibility that both Latin and Persian were fashioned and maintained as imperial languages by the parallel and sometimes conjoined efforts of poets and of bureaucrats seems quite real.

\section{FACTORS AFFECTING THE CONDITION OF LATIN AFTER ANTIQUITY}

About the post-antique period, though it is longer, I will be briefer. In this period, Latin remains an imperial language, but in contrast to Persian, the trajectory followed by Latin during this time has been characterized mainly by entropy. While institutional factors, such as the use of Latin by the Roman Catholic Church and by European universities, for a long time helped Latin to maintain an important role, its role as a truly imperial language was behind it by the time that Persian had just begun to come into its own. In this section, I will try to state briefly how the conditions that supported latinity during antiquity changed in the post-antique period, and where possible I will compare or contrast these developments with relevant ones in Persian.

\section{Bilingualism}

As I have been saying, one of the main parameters of Latin's development as an imperial language in antiquity was its sustained contact with Greek. With the division of the Roman Empire into eastern (i.e., Byzantine Greek) and western (latinate) halves, a long period of elite Latin-Greek bilingualism came to an end. It was replaced by a period in which literary Latin came to be defined as the only language of the elite. This language remained relatively stable, as it had done in antiquity. The spoken dialect, however, which had always diverged to some extent from the written, as we have seen, developed in ways (such as the loss of certain morphological features and the consequent need to represent syntactic relationships in ways that did not depend so much on morphology) that caused it to 
diverge more and more from the language of the elite. Some of these features are common to all of the modern Romance languages; but the very fact that these languages are distinct, not only from Latin but from each other, shows clearly that vulgar Latin and proto-Romance were more open to regional variation than the elite dialect. This is because, as I have said, the elite dialect was always susceptible to "correction" by appeal to grammar. But one such effort is instructive about the differences between the Latin of antiquity and that of later times. When the Saxon scholar Alcuin came to Charlemagne's court, he was appalled at the state of latinity that prevailed there. Of course, as a native speaker of a Germanic language, Alcuin learned Latin as a wholly foreign tongue, as the language of a governmental and cultural elite. On the continent, it was possible to distinguish between more or less cultivated latinity, but there was as yet no sharp distinction between Latin and Romance; at any rate, the "elite" Latin spoken at court resembled all too much, to Alcuin's ears, the vulgar Latin or proto-Romance spoken by commoners out on the street. The situation moved Alcuin to "restore" continental Latin on grammatical lines, a move that became influential by virtue of a concommitant reform of Carolingian schooling. This intervention is an important episode in the history of Latin as the imperial language of medieval Europe. But it may be even more important in having finally separated the classical (or classicizing, since Alcuin's standards were not identical with those of antiquity) from the vulgar dialect and allowing the former to remain relatively fixed while the latter went on to develop into a number of wholly different languages.

In tandem with this colossally important development we must reckon with at least three others that altered the character of Latin after antiquity.

\section{Religion}

The first of these is religion. In antiquity, Latin was of course used as a religious language by the Romans, just as Greek was used by the Greeks, and so on. But neither language as such was marked as a religious language. Religious utterances had their own style, characterized by specific lexical, syntactic, and rhetorical elements, and above all by an almost pathological conservatism. But Latin itself was not, for the Romans, a religious language any more (or any less) than it was a legal language, a diplomatic language, or what have you.

With the advent of Christianity, this situation changed. In the first place, the Roman Church adopted Latin as its official language. This meant, of 
course, that when the secular power of the Empire disintegrated, there was still a latinate central whose authority extended throughout Europe. As I have just been saying, however, as the difference between the elite and vulgar dialects increased, the language of the Church, and especially of liturgy, became more and more marked as Latin in contrast to the vernacular that most people spoke. To this was added the fact that the Church regarded Latin, along with Greek and Hebrew, as the tres linguae sacrae ("three sacred languages") because of the trilingual inscription "Here is the King of the Jews" that was affixed to Jesus' cross. Greek and Hebrew, of course, were largely unknown in the West, leaving Latin for all practical purposes as the only "sacred language" that anyone ever encountered.

The situation is thus very different from that of Persian in the early centuries of Arab rule. Arabic was, of course, in early Islamic Persia a sacred language par excellence. Persian, at that point anyway, was not. The development of Persian in these early centuries was, therefore, perhaps facilitated by not having to bear this burden. In medieval Europe, by contrast, the language of the elite was marked as a sacred language, enhancing its prestige, perhaps, but also distancing it that much more from the realities of everyday speech.

\section{Vernacular Languages}

John Perry states an important corollary to this last point: Early New Persian "stood in much the same relationship (from a linguistic and a socioreligious perspective) as Early Romance to Late Latin in Europe of the same period." In some sense, then, we should perhaps regard Latin as playing something like the same role in Europe between, say, the 9th and the 12th centuries, that Arabic played in Persia between the 7th and the 11th. Both languages dominated the religious sphere, and they were the language of the elite, whether old (as in Europe) or new (as in Persia). One limit to this comparison is that Latin at this time was a language of literature and of the other arts and sciences, while Arabic, as yet, was not. As I have already observed, it was Arabic contact with Persian (and with Greek and other languages, such as Syriac) that helped it become an imperial language in the realm of secular culture, as happened to Latin via contact with Greek in an earlier period. But the fact that Arabic was ill-equipped to overwhelm Persian in the realm of secular culture allowed Persian room to develop and to serve as a catalyst for the development of Arabic in the same field. In 
Europe, it took time for a distinctive vernacular elite language - the theme of Dante's De vulgari eloquentia - and culture to develop and eventually to surpass that of Latin.

\section{Collective Identities}

The role of collective identities in this story is too complex to address in any detail. I have occasionally spoken of "regional variations" or "vernacular traditions" in the development of Latin and Romance. For a long time, the central authority of the Roman Church was able to counterbalance the centrifugal tendencies of local power throughout the continent. Ultimately, this power was broken, and the history of Europe is best understood in terms of the nation state-its roots, its myths of ethnic identity, and the institutions that support these ideas, among which national language takes pride of place. The point is that Latin has been, certainly since the Reformation and arguably since the end of antiquity, still the language of an empire, yes, but one that was doomed over the long run to fighting a rear-guard action, cutting its losses, and shoring fragments against its ruins. Persian might have been seen to be in such a position between the end of the Achaemenian Empire until AD 226, when the Persian nationalist Ardashir I had himself crowned ShāhanShāh at Ctesiphon, much as Charlemagne in 800 was crowned Emperor at Rome. But it was only after the Persian revival of the Sasanians that the language went on, chiefly under foreign rulers, to enjoy true imperial status. After Charlemagne--beginning, in fact, with the quarrels that divided his immediate successors - ethnic forces would play a decisive role in the rise of modern states, to which Latin would become increasingly irrelevant.

\section{Grammar, Education, and Literary Canon}

Alcuin's reforms were successful in distinguishing Latin from vernacular speech. In so doing, they may also have cut the language off from an important source of renewal and rendered it less flexible than it needed to be to adapt to a changing world. In this way, Alcuin may have established a pattern followed by most subsequent Latin educators of rejecting any form of the language that could not be justified by direct appeal to ancient practice.

The most extreme form of this attitude is represented by the Humanist quarrel over Ciceronianism. It was, of course, a concern of the Humanists, as it had been of Alcuin, to reform the language. It is an irony that the standard medieval Latin that they scorned in comparison to that of the 
ancients was probably created, or at any rate codified, by the reforms that Alcuin instituted with very similar goals in mind. But with access to many more ancient texts the Humanists were able to cultivate a more thoroughly classicizing style. The problem was how far to go. It occurred to some writers, as of course it would, that living in a world different from that of the Romans, they would occasionally find it necessary to talk about things that had been unknown to the Romans. How could one do so in a purely classical idiom. The problem has been faced many times in many languages, but the decision proposed by some Humanists with regard to Latin may be unique. For Lorenzo Valla and others, the works of Cicero should be the one and only standard of correct latinity. Valla was opposed by men such as Angelo Poliziano and others; later Ciceronians were opposed by no less a figure than Erasmus. And it would be impossible to say that the dispute was ever universally resolved. But the fact that men like Valla could advocate such a narrow basis for correct latinity shows to what extent, even in the era of its supposed "rebirth," Latin had advanced towards becoming a corpus language.

\section{Cultural Institutions}

The institutional support for Latin was clearly different in the middle ages from what it had been in antiquity. Instead of dramatic festivals, imperial libraries, and the like, Latin became the preserve of monasteries and cathedral schools. These places, together with such institutions as the Vatican chancery, are the principal setting within which the influence of professional administrators is to be sought. Again, in contrast to antiquity, it seems difficult to credit the medieval formularies, the ars dictandi manuals, and so forth - many of them described as "anything but models of good Latinity; with the exception of the Letters (Varae) of Cassiodorus, and the St. Gall collection 'Sub Salomone,' they are written in careless or even barbarous Latin, though it is possible that their wretched 'style' is intentional, so as to render them intelligible to the multitude"-with making a very positive contribution to the survival of Latin. ${ }^{32}$ With the rise of universities, some aspects of ancient scholarship were eventually restored; but inevitably the vernacular languages became media of scholarly communication, to the extent that the advantages even of an academic lingua franca such as Latin offered were not outweighed by the necessity of learning several modern languages in order to stay abreast of current research. 


\section{CONCLUSION}

In sum, there are clearly many points of similarity between the imperial histories of Latin and Persian. Chief among these, as it seems to me, is the way in which these languages interacted with others in the course of taking on their imperial character. The interaction between belles lettres and administrative language in medieval Persia and in Roman antiquity seems another promising area for further study. On balance, however, the differences between these two histories may be even more intriguing than the similarities. It would be fascinating to raise many of these same questions especially in regard to those languages, Arabic and Greek, that played such in important role in the histories of Persian and Latin, to say nothing of other, less directly related imperial traditions.

\section{NOTES}

1. On the spread of Latin and the survival of other languages see R. MacMullen, "Provincial Languages."

2. Estimates vary from about 60 to 120 million, depending largely on whether one means to estimate the size of the citizen population alone or of the entire human population of the Empire.

3. About 60 percent of the population is thought to have lived in the eastern provinces during the age of Constantine and Justinian. Latin will have been the mother tongue of the great majority in the west, but by no means of all. No doubt it was spoken as a second language, with varying degrees of fluency, throughout the Empire. On bilingualism see J.N. Adam, Bilingualism and the Latin Language.

4. On Alcuin's role in this story see Roger Wright, Late Latin.

5. The prevailing view that Old Persian was used only as a ceremonial language is challenged by a text that was recently discovered in the Persepolis Fortification archive at the Oriental Institute of the University of Chicago. The text is the first and so far the only known administrative document written in Old Persian. As such, it could be "just a quirky experiment" or else "the tip of an iceberg," according to Matthew W. Stolper, head of the Oriental Institute's Persepolis Fortification Archive Project (http:/ /wwwnews.uchicago.edu/releases/07/070615.oldpersian.shtml).

6. In truth, one might argue that both Greek and Aramaic have endured as well. Greek gradually replaced Latin as the official language of the Byzantine Empire, held that status until the fall of Constantinople in 1453, remained in common use under Ottoman rule, and is of course today the official language of a modern nation state. The estimated number of speakers runs from 15 to 25 million people (R. Browning, Medieval and Modern Greek). Varieties of Aramaic remained important throughout the Middle Ages and into the modern period especially for scriptural and liturgical purposes; but the number of native speakers has dwindled to about 500,000, and the fragmentation of spoken dialects is such that many groups of Aramaic speakers can no longer understand one another. On July 31, 2006, the Arameans of Aram-Naharaim 
Foundation presented their case to the UNESCO Working Group on the Indigenous Populations that Aramaic must now be considered an endangered language.

7. Epist. 2.2.157.

8. Sander Goldberg, Constructing Literature, 1.

9. The earliest known Roman writer of history is Fabius Pictor, who was himself a senator (Polybius 3.9.4). Other Romans of this period who wrote in Greek include L. Cincius Alimentus, C. Acilius, and A. Postumius Albinus. The surviving fragments of their works can be found in F. Peter, Historicorum Romanorum reliquiae.

10. For an overview of the situation (one that stresses the influence of Greek in the service of explaining the supposed "decline" of Latin literature in the 1st and 2nd centuries AD), see Gordon Williams, Roman Literature, Ch. 3, "The Dominance of Greek Culture," esp. 138-58.

11. Aulus Gellius NA 19.8.15.

12. Joseph Farrell, Latin Language, 18.

13. Both words for "horse" (equus and caballus), for instance, exhibit the regular-um ending of the second-declension accusative, signalling that the word is the direct object of the main verb. It would be easy to find examples of vulgar Latin, however, in which this ending had been replaced by -us, the nominative. In both of these endings, the final consonant was but weakly pronounced, and in Romance both developed into $-u$ and, eventually, into -o (as Latin caballus/caballum became Spanish caballo/caballo and Italian cavallo/cavallo).

14. The lexical differences, such as equus v. caballus, are obvious. The usual word-order of classical Latin is SOV (subject-object-verb), while the vulgar dialect (like Romance) is SVO. The classical dialect is spare, using personal pronouns (such as ego) mainly for emphasis (since the information they convey is already contained in the ending of the verb), dispensing with the indefinite article unus, preferring the simple to the compound form of the perfect tense, etc. On the history and characteristic features of vulgar Latin see József Herman’s Vulgar Latin.

15. On the situation in regard to Latin see Herman, "Spoken and Written Latin."

16. Estimates of the literacy rate in Greek and Roman antiquity are very controversial. The fullest analysis of the evidence is that of W.V. Harris's Ancient Literacy, which argues that the literacy in the Roman Empire never exceeded 10 percent of the total population. But Harris's methods are regarded by many as too conservative: see for instance the responses of Mary Beard et al., "Literacy in the Roman World." For some scholars the question turns on the definition of literacy. It seems clear that there were different degrees or kinds of literacy and that any individual might be proficient in one or more, but not all of them. Thus the number of people who were literate in commercial matters but who could not easily understand a relatively challenging author like Lucan or Juvenal might be much larger than 10 percent of the total population. What seems clear is that literacy rates, especially in cities, were higher and perhaps much higher during the Empire than was typical of most premodern cultures; but it is very difficult to be more specific than that.

17. Dionysius of Halicarnassus states that "The Romans speak a language that is neither entirely foreign (barbaron) or quite Greek, but rather a mixture of the two. It is mainly Aeolic [one of the three main dialects of classical Greek], and the only defect, which is the result of their absorbing so many peoples, is that they do not maintain proper pronunciation. Otherwise they preserve the evidence of their Greek ancestry better than 
any other colonists" (Ant. Rom. 1.90.1). This theory was probably developed by Greek intellectuals whose amour propre was offended by their political subservience to Rome.

18. On classical canon formation see Mario Citroni, "Concept of the Classical and the Canons of Model Authors in Roman Literature," 204-34.

19. On these groups see A. Spawforth, Oxford Classical Dictionary, s.v. "Dionysus, artists of," with further references.

20. The bequest was controversial at Rome, and the disposition of the library is uncertain. On Attalus III and the Attalid dynasty in general see Esther V. Hansen, Attalids of Pergamon.

21. Probably the best known private library is the one that was found at Herculaneum in the Villa dei Papiri, presumed to be the property of L. Calpurnius Piso Caesoninus, consul in 58 BC and father-in-law of Julius Caesar. Over 1800 books have been found; most are works of Greek philosophy, but several works of Latin poetry are represented as well. The books are in containers and were evidently in the process of being rescued from the impending eruption of Vesuvius in AD 79 when the situation got out of hand and the villa was buried in lava. It is known that additional books remain unrecovered, and it is thought that the number of these may be quite large, but certainty about this and other aspects of this important library awaits further exploration.

22. In antiquity about 130 plays circulated under Plautus' name; on the whole problem see Gellius, NA 3.3.

23. Similarly Quintilian's canon is divided into separate lists of Greek (IO 10.1.46-84) and Roman (85-131) authors.

24. Andrew Wallace-Hadrill, "Mutatio morum: The Idea of a Cultural Revolution," 3-22.

25. Suetonius, Div. Vesp. 18.

26. It is true that Thomas Habinek (Politics of Latin Literature) has argued against the idea that poets like Horace-or like Ovid, the poet with whom Habinek is chiefly concerned (pp. 151-69)—should be set apart from writers of other kinds because of their superior imagination or craftsmanship. On Habinek's view, which derives from recent studies of writing under the British colonialism in the 19th century, all writing does the work of empire.

27. On this institution see Nicholas Horsfall, "Collegium Poetarum," 79-95.

28. Edward Courtney, Archaic Latin Prose, 98

29. De legibus 2.59.9.

30. On the annales maximi see B.W. Frier, Libri annales pontificum maximorum; Elizabeth Rawson, "Prodigy Lists."

31. A.N. Sherwin-White, Letters of Pliny, 536-46.

32. A. Boudinhon, Catholic Encyclopedia, "formularies."

\section{REFERENCES}

Adam, J.N. 2005. Bilingualism and the Latin Language. Cambridge: Cambridge University Press.

Beard, Mary, ed. 1991. Literacy in the Roman World. Journal of Roman Archaeology, Supplementary series 3. Ann Arbor.

Boudinhon, Auguste. 1909. Formularies (libri formularum). In The Catholic En- 
cyclopedia, Vol. 6. New York: 22 Jun. 2009 <http://www.newadvent.org/ cathen/06141a.htm>.

Browning, R. 1983. Medieval and Modern Greek. 2d ed. Cambridge: Cambridge University Press.

Citroni, Mario. 2005. The Concept of the Classical and the Canons of Model Authors in Roman Literature. In Classical Pasts: The Classical Traditions of Greece and Rome, ed. J. Porter, pp. 204-34. Princeton: Princeton University Press.

Courtney, Edward. 1999. Archaic Latin Prose. Atlanta, GA: Scholars Press.

Farrell, Joseph. 2001. Latin Language and Latin Culture from Ancient to Modern Times. Cambridge: Cambridge University Press.

Frier, B.W. 1979. Libri annales pontificum maximorum: The Origins of the Annalistic Tradition. Papers and Monographs of the American Academy in Rome, vol. 27. Reprint (Ann Arbor: University of Michigan Press, 1999).

Goldberg, Sander. 2005. Constructing Literature in the Roman Republic. Cambridge: Cambridge University Press.

Habinek, Thomas. 1998. The Politics of Latin Literature: Writing, Identity, and Empire in Ancient Rome. Princeton: Princeton University Press.

Hansen, Esther V. 1971. The Attalids of Pergamon. Ithaca: Cornell University Press.

Harris, W.V. 1989. Ancient Literacy. Cambridge, MA: Harvard University Press. Herman, József. 1996. Spoken and Written Latin in the Last Centuries of the Roman Empire. A Contribution to the Linguistic History of the Western Provinces. In Latin and the Romance Languages in the Early Middle Ages, ed. Roger Wright, pp. 29-43. University Park, PA: Pennsylvanian State University Press.

2000. Vulgar Latin, trans. Roger Wright. University Park, PA: Pennsylvania State University Press.

Horsfall, Nicholas. 1976. The Collegium Poetarum. Bulletin of the Institute of Classical Studies 23:79-95.

MacMullen, Ramsay. 1966. Provincial Languages in the Roman Empire. American Journal of Philology 87:1-14.

Peter, F. 1914. Historicorum Romanorum reliquiae. 2nd ed. Leipzig: Teubner.

Rawson, Elizabeth. 1971. Prodigy Lists and the Use of the Annales Maximi.

In Classical Quarterly 21:158-69. Republished in Roman Culture and Society (Oxford: Oxford University Press, 1991), 1-15.

Sherwin-White, A.N. 1966. The Letters of Pliny: A Historical and Social Commentary. Oxford: Oxford University Press.

Spawforth, Antony. 2001. Dionysus, Artists of. In The Oxford Classical Dictionary, 3rd ed., ed. Simon Hornblower and Antony Spawforth, pp. 482-83. Oxford: Oxford University Press.

Stolper, Matthew W. 2007. Persepolis Fortification Archive Project, Oriental Institute (http: / / www-news.uchicago.edu/ releases / 07 / 070615.oldpersian.shtml). 
Wallace-Hadrill, Andrew. 1998. Mutatio morum: The Idea of a Cultural Revolution. In The Roman Cultural Revolution, ed. Thomas Habinek and Alessandro Schiesaro, pp. 3-22. Princeton: Princeton University Press.

Williams, Gordon. 1978. Change and Decline: Roman Literature in the Early Empire. Berkeley: University of California Press.

Wright, Roger. 1982. Late Latin and Early Romance in Spain and Carolingian France. Liverpool: F. Cairns. 